\section{Re: Menneskerettigheter, klima og global helse i Legeforeningen}

Jeg viser til innlegg i Tidsskriftet nr. 6/2017 (1) der tidligere medlemmer av Legeforeningens utvalg for menneskerettigheter, klima og global helse er kritiske til at sentralstyret i sitt møte i november 2016 besluttet å omorganisere dette arbeidet.

Legeforeningen opprettet i 1991 utvalg for menneskerettigheter. Senere ble utvalg for klimaendringer og utvalg for global helse opprettet. Selv om utvalgene hadde ulike mandat, var det også noen overlappende arbeidsområder som for eksempel retten til helse. Sentralstyret besluttet å slå sammen utvalgene til ett utvalg for menneskerettigheter, klima og global helse. Utvalgene har gitt viktige bidrag til å utforme Legeforeningens standpunkter på en rekke områder.

Menneskerettigheter, klima og global helse vil fortsatt være et prioritert område, selv om Legeforeningen nå velger å omorganisere arbeidet. Sentralstyret er opptatt av å utnytte Legeforeningens samlede engasjement på en best mulig måte. De fagmedisinske foreningene har de siste årene fått en større betydning i Legeforeningens virksomhet. Sammen med yrkesforeningene har de et bredt internasjonalt engasjement og bidrar aktivt i utformingen av Legeforeningens politikk på ulike områder. Disse foreningene vil kunne åpne opp for en bredere tilnærming enn et eget utvalg med bredt mandag.

Sentralstyret har vedtatt fem hovedområder som det skal arbeides videre med: Leger i utsatt posisjon, barn i fengsel/Politiets utlendingsinternat, assistert befruktning som eggdonasjon og surrogati, helse og global oppvarming og aldersbestemmelse av mindreårige asylsøkere. Sentralstyret vil spesielt følge utviklingen i Tyrkia der leger og andre akademikere nå er særlig utsatt. Sentralstyret har besluttet at det skal nedsettes en arbeidsgruppe som skal se nærmere på hvordan opphold i fengselsliknende institusjoner som Politiets utlendingsinternat påvirker barns helse og hvilke helsetiltak som må tilbys barn som tvangsutsendes. Sekretariatet utarbeider et notat om assistert befruktning som forberedelse til bioteknologimeldingen. Det globale klimaengasjementet vil blant annet bli fulgt opp gjennom WMA, men sentralstyret vil også ta nasjonale klimainitiativ når det er naturlig. Videre skal organiseringen av arbeid med menneskerettigheter, klima og global helse evalueres ved sentralstyrets årlige gjennomgang av dette arbeidet.

Retten til helse slik den er nedfelt i FNs konvensjon om økonomiske, sosiale og kulturelle rettigheter, danner grunnlaget for Legeforeningens engasjement for menneskerettigheter.

Sentralstyret vil at Legeforeningen fortsatt skal ha en betydelig aktivitet innenfor dette området og ser at det kan være nyttig å ha et fast utvalg for utforme Legeforeningens synspunkter på disse temaene. Et fast utvalg som arbeider over tid, vil utvikle viktig kompetanse, men mandatet for utvalget ble for bredt. En mulighet er å opprette et utvalg med et snevrere mandat for å ivareta Legeforeningens arbeid med menneskerettigheter.

\section{Marit Hermansen}

marit.hermansen@legeforeningen.no

Marit Hermansen er president i Den norske legeforening

Ingen oppgitte interessekonflikter.

\section{Litteratur}

1. Steinholt M, Engjom H, Annexstad E et al. Menneskerettigheter, klima og global helse i Legeforeningen. Tidsskr Nor Legeforen 2017; 137: 432.

\section{Re: Hvor mange skader behandler spesialisthelsetjenesten årlig?}

I Tidsskriftet nr. 23-24/2016 hevder Børge Ytterstad at det er en stor underrapportering av skader i Norge (1). Det samme budskapet fremfører han i et intervju i Dagens Medisin 25. november (2).

Helsedirektoratet er enig med Ytterstad at det er en stor underrapportering av personskader via Felles minimums datasett, hvor sykehusene skal registrere omstendighetene rundt skadene de behandler. Registrering av når, hvor og hvordan skader oppstår er et viktig ledd i det forebyggende arbeidet. Imidlertid er det deler av Ytterstads argumentasjon som bør nyanseres. Helsedirektoratet vil gjerne bidra med slik oppklarende informasjon.

I Tidsskriftets artikkel fremsettes også påstander om at Helsedirektoratets tall på antallet behandlede skader i spesialisthelsetjenesten er for lavt. Helsedirektoratets tall viser at $i$ overkant av 300000 skader årlig behandles i spesialisthelsetjenesten (3). Ytterstad sier at rapporteringen via ICD-10-koder er for lav, og viser til en skaderapport av Guldvog og medarbeidere fra 1992, samt egne tall fra Harstad, for å argumentere for at det reelle antallet skader behandlet i spesialisthelsetjenesten er på 500000 per år.

For å beregne antallet skader behandlet i spesialisthelsetjenesten bruker Helsedirektoratet Hoveddiagnose ICD-10 kapittel XIX, kodene S00-T78. Hoveddiagnosen er diagnosen som gis for den tilstanden som er hovedårsaken til at pasienten trenger behandling eller undersøkelse på sykehus. Den siterte rapporten fra 1992 tar utgangspunkt i skader behandlet $\mathrm{i}$ «emergency departments or hospitals». Disse tallene er blant annet hentet fra de kommunale legevaktene i Drammen, Stavanger, Trondheim og Harstad som var med i Folkehelsas tidligere skaderegister. Disse legevaktene er ikke spesialisthelsetjenesten, men primærhelsetjenesten.

Ytterstad viser også til egne tall fra UNN Harstad for å vise at insidens av skader (?) er på 10 per 100 personår for alle aldre og begge kjønn. Norske helseforetak er ulikt organisert, og det vil derfor være betydelig variasjon i nevnte insidens. Dette fordi enkelte kommuner vil ha en kommunal legevakt som behandler de fleste skadene, mens for eksempel Oslo og Bergen har legevakter som er organisert under OUS og Helse Bergen, og derfor vil ha samme typer skader som går rett inni statistikken til spesialisthelsetjenesten. En plausibel forklaring på den høye insidensen i Harstad kan være at den lange tradisjonen med grundig skaderegistrering ved sykehuset, har ført til at flere skader behandles (og registreres) i spesialisthelsetjenesten, og færre i primærhelsetjenesten.

Helsedirektoratet mener at anslaget på drøyt 300000 skader er et godt bilde på mengden skader behandlet i spesialisthelsetjenesten. For å få gode nasjonale estimat på samlet antall skader bør en inkludere ICPC-koder for skader i primærhelsetjenesten. Dette er også gjort av Folkehelseinstituttet i rapporten «Skadebildet i Norge» (4) fra 2014. Denne rapporten anslår at ca. 540000 skader årlig ble behandlet i primær- og spesialisthelsetjenesten til sammen i perioden 2009-2011.

Helsedirektoratet stiller seg for øvrig bak Ytterstads ønske om bedre skaderegistrering. Det beste virkemiddelet for å oppnå dette er at sykehusene fyller ut omstendighetene til skadene de behandler via Felles minimums datasett. Da vil Helsedirektoratet og helsetjenesten også få bedre informasjonsgrunnlag for å drive skadeforebygging.

\section{Stein Olav Gystad}

Stein.Olav.Gystad@helsedir.no

Stein Olav Gystad er avdelingsdirektør i Helsedirektoratet.

Ingen oppgitte interessekonflikter.

Litteratu

1. Ytterstad B. Hvor mange skader behandler spesialisthelsetjenesten årlig? Tidsskr Nor Legeforen 2016; 136: 1970. 